\title{
The Genetic Relationship between Commencement of Luteal Activity and Calving Interval, Body Condition Score, Production, and Linear Type Traits in Holstein-Friesian Dairy Cattle
}

\author{
M. D. Royal, ${ }^{\star}$ J. E. Pryce,† J. A. Woolliams,‡ and A. P. F. Flint ${ }^{\star}$ \\ *Division of Animal Physiology, School of Biosciences, \\ University of Nottingham, Sutton Bonington Campus, \\ Leics, LE12 5RD, United Kingdom \\ †Animal Biology Division, Scottish Agricultural College, \\ Edinburgh, EH9 3JT, United Kingdom \\ $\ddagger$ Roslin Institute (Edinburgh), Roslin, Midlothian, EH25 9PS, United Kingdom
}

\begin{abstract}
The decline of fertility in the UK dairy herd and the unfavorable genetic correlation $\left(r_{\mathrm{a}}\right)$ between fertility and milk yield has necessitated the broadening of breeding goals to include fertility. The coefficient of genetic variation present in fertility is of similar magnitude to that present in production traits; however, traditional measurements of fertility (such as calving interval, days open, nonreturn rate) have low heritability $\left(\mathrm{h}^{2}<0.05\right)$, and recording is often poor, hindering identification of genetically superior animals. An alternative approach is to use endocrine measurements of fertility such as interval to commencement of luteal activity postpartum (CLA), which has a higher $\mathrm{h}^{2}(0.16$ to 0.23 ) and is free from management bias. Although CLA has favorable phenotypic correlations with traditional measures of fertility, if it is to be used in a selection index, the genetic correlation $\left(\mathrm{r}_{\mathrm{a}}\right)$ of this trait with fertility and other components of the index must be estimated. The aim of the analyses reported here was to obtain information on the $r_{a}$ between lnCLA and calving interval (CI), average body condition score (BCS; one to nine, an indicator of energy balance estimated from records taken at different months of lactation), production and a number of linear type traits. Genetic models were fitted using ASREML, and $r_{a}$ were inferred from genetic regression of lnCLA on sire-predicted transmitting abilities (PTA) for the trait concerned by multiplying the regression coefficient $(b)$ by the ratio of the genetic standard deviations. The inferred $\mathrm{r}_{\mathrm{a}}$ between $\operatorname{lnCLA}$ and CI and average BCS were 0.36 and -0.84 , respectively. Genetic correlations between lnCLA and milk fat and protein
\end{abstract}

Received January 11, 2002.

Accepted March 27, 2002.

Corresponding author: M. D. Royal; e-mail: melissa.royal@notting ham.ac.uk. yields were all positive and ranged between 0.33 and 0.69. Genetic correlations between InCLA and linear type traits reflecting body structure ranged from -0.25 to 0.15 , and between udder characteristics they ranged from -0.16 to 0.05 . Thus, incorporation of endocrine parameters of fertility, such as CLA, into a fertility index may offer the potential to improve the accuracy of breeding value prediction for fertility, thus allowing producers to make more informed selection decisions.

(Key words: milk progesterone, calving interval, body condition score, linear type traits)

Abbreviation key: $\mathbf{C I}=$ calving interval, $\mathbf{C L A}=$ interval to commencement of luteal activity postpartum, HUKI = Holstein UK and Ireland, PCH = percentage Holstein, PIN95 = 1995 profit index, $\mathbf{r}_{\mathbf{a}}=$ additive genetic correlation.

\section{INTRODUCTION}

Over the last $20 \mathrm{yr}$, the dairy industry has witnessed severe phenotypic declines in fertility. Calving rates to first service have fallen by as much as $0.45 \%$ in the US (Butler and Smith, 1989; Beam and Butler, 1999) and $1 \%$ per annum in the UK, and the typical UK herd now has a first service calving rate of approximately 40\% (Darwash et al., 1999; Royal et al., 2000a; P. J. $\mathrm{H}$. Ball, personal communication). In addition to this phenotypic decline, fertility has declined genetically. Selection for increased milk production (which is unfavorably correlated to fertility as discussed below) has resulted in unfavorable genetic trends in fertility. For example, the genetic trend in days open in Finnish Ayrshire bulls born between 1980 and 1989 showed an increase of $0.43 \mathrm{~d}$ per annum (Juga et al., 1999). Similarly, in the Netherlands, the genetic trend in calving interval showed an increase of $0.20 \mathrm{~d}$ per annum for bulls born between 1980 and 1991 (Pryce and Veerkamp, 1999). 
The analyses of milk progesterone profiles have shown that a number of atypical ovarian patterns are phenotypically associated with reduced fertility in the UK dairy cow (Darwash et al., 1997a; Royal et al., 2000a). Three such patterns-interval to commencement of luteal activity (CLA) postpartum, persistent corpus luteum type I, and length of the first luteal phase postpartum-have moderate levels of heritability in today's Holstein Friesian population of dairy cattle (Darwash et al., 1997b; Royal, 1999; Veerkamp et al., 2000; Royal et al., 2000b, 2002). Genetic regressions of lnCLA on sires' PTA for milk, fat, and protein yield and one of the UK's national dairy selection indices related to production, the 1995 profit index (PIN95), are highly unfavorable (Royal et al., 2000b, 2002). Furthermore, the additive genetic correlation $\left(\mathbf{r}_{\mathbf{a}}\right)$ between predicted peak milk yield (d 56) and lnCLA is large (0.36) and unfavorable (Royal et al., 2002). Other studies (Pryce et al., 2000) have reported a moderate and negative $r_{a}(-0.40)$ between a traditional measure of fertility, calving interval, (CI), and average BCS (an indicator of energy balance), in addition to moderate $r_{a}$ with a number of linear type traits (e.g., 0.33, 0.47 with stature and angularity, respectively), indicating that taller, more angular cows have longer CI.

To assess the usefulness of CLA in future breeding programs to improve fertility, it is necessary to determine $r_{a}$ with traits in the breeding goal or used in selection indices, such as CI, production, and linear type traits. In the UK, linear type traits and BCS are routinely recorded by Holstein UK and Ireland (HUKI). For herds that are part of the linear type classification scheme, it is compulsory to have heifers classified to provide information for sire type PTA estimation (Brotherstone and Hill, 1991). Trained classifiers record type traits on a linear scale from 1 to 9 according to biological extremes (e.g., for stature 1 is very short and 9 is very tall). BCS is used to assess the amount of body fat. The assessment is made visually and/or by touch, on the tail head and/or the loin area. It is used by many farmers as a management aid in deducing how well the current feeding needs are being met relative to stage of lactation in dairy cows. BCS and angularity are genetically correlated with CI (Pryce et al., 2000) and may also be good indicators of CLA. In addition, $\mathrm{r}_{\mathrm{a}}$ between BCS and angularity is high. Where $\mathrm{r}_{\mathrm{a}}$ between type and breeding goal traits are high, type information can be used to provide additional information. For example, other type traits (udder depth, foot angle, fore udder attachment, and teat length) are currently used to predict lifespan PTA (lifespan is the measure of longevity used in the UK) where actual lifespan information is not available or is sparse (Brotherstone et al., 1997). Therefore, type information may also be valuable in predicting fertility.

Little information is available on the genetic relationships between endocrine and traditional reproductive traits, and linear type traits commonly used in selection programs. As an initial step towards filling this gap in knowledge, a database of over 1200 records on cows with CLA and pedigree information was related via common sires to estimated PTA for CI, production, linear type traits, and average BCS. The objectives of the current analyses were to estimate genetic regressions of lnCLA on the described sire PTA values and to obtain some preliminary evidence on the sign and magnitude of genetic correlations.

\section{MATERIALS AND METHODS}

\section{Sire PTA Data}

In a previous study by Pryce et al. (2000), PTA for CI and average BCS were estimated using the prediction and estimation program, part of the variance component and estimation suite (Groeneveld, 1998). Heifers were scored only once during a lactation, and, therefore, the resulting sire BCS PTA is considered to be an average BCS (adjusted to lactation one) since the scores were not taken on set days relative to calving. Month of lactation was fitted to the statistical model for BCS as a covariate to adjust for milk yield. Components used to estimate breeding values such as (co)variance components and genetic parameters were estimated using bivariate and univariate models, respectively. In estimating (co)variance components, the following restrictions have been made to the data: CI were restricted to between 300 and $600 \mathrm{~d}$, each sire had to have a minimum of five daughters, and there were a minimum of 20 cows per herd-year subclass. For further details of models fitted, and data editing methods see Pryce et al. (2000). Means, standard deviations, and heritabilities for CI and average BCS data utilized to estimate the PTA used in the current analyses are presented in Table 1.

Of the 169 sires from the milk progesterone database (described below), 124 had average BCS and CI proofs, 167 had national production proofs (estimated by the Animal Data Centre) and 143 had conformation proofs (estimated by HUKI).

As there were relatively few sires in common between the milk progesterone and the sire PTA database, no further restrictions were made. Sires represented in the final data were generally bulls that were used extensively, and thus the accuracies were $>0.7$. A summary of statistics for the sire PTA used in these analyses are presented in Table 2 . 
Table 1. Number of records, means, phenotypic standard deviations (SDp), coefficients of genetic variation $(\mathrm{CVa})$, heritability $\left(\mathrm{h}^{2}\right)$, and genetic standard deviations (SDa) for the data used to estimate PTA for BCS and calving interval (Pryce et al., 2000a).

\begin{tabular}{lll}
\hline & BCS & CI \\
\hline Number of records & 44,622 & $19,042^{*}$ \\
Range & $1-9$ units & $300-600 \mathrm{~d}$ \\
Mean & 3.9 units & $385 \mathrm{~d}$ \\
SDp & 1.3 units & $45.3 \mathrm{~d}$ \\
CVa $(\%)$ & 17 & 1.6 \\
Heritability & 0.28 & 0.022 \\
SE of ${ }^{2}$ & 0.01 & 0.005 \\
SDa & 0.69 & 6.7 \\
\hline
\end{tabular}

*CI records are a subset of BCS records.

\section{Milk Progesterone Database Formation}

Milk progesterone and veterinary treatment. Progesterone profiles were available on all cows in the database as a result of progesterone measurement in milk samples taken three times weekly, as described by Royal et al. (2000a). Treatment for reproductive failure with hormones was withheld until d 80 postpartum during collection of this progesterone data (unless required for welfare reasons); therefore, treatment was not a factor considered to affect CLA in this study. Animals experiencing dystocia, retained placenta, and/or uterine infection were recorded, and these effects were included in the final analyses. CLA, the endocrine fertility trait analyzed in this study, is described in full in Royal et al. (2000a).
Pedigree and performance records. Lactation and reproductive performance data from the milk progesterone database, in addition to information from two commercial databases (National Milk Records Plc, Chippenham, UK and HUKI Ricksmanworth, UK) were combined. Information from the milk progesterone database, related to 1212 lactations, was collected between October 1996 and March 1999.

Three-generation pedigrees were obtained for all cows in the study (i.e., up to and including greatgrandparents). Wherever possible this was extracted from the HUKI database. Milk records were obtained from the NMR database for all cows, except those of Roslin Institute, which were directly available.

The Holstein percentages (PCH) of all cows in the study were either obtained from the HUKI database

Table 2. Number of sires, average sire PTA, standard deviation of PTA (SD), and minimum accuracies for all traits investigated in the current analysis.

\begin{tabular}{|c|c|c|c|c|}
\hline Trait & $\begin{array}{l}\text { Number } \\
\text { of sires }\end{array}$ & $\begin{array}{l}\text { Average } \\
\text { PTA }\end{array}$ & $\mathrm{SD}$ & $\begin{array}{l}\text { Minimum } \\
\text { accuracy }\end{array}$ \\
\hline CI & 124 & 1.73 & 2.43 & $0.72^{1}$ \\
\hline $\mathrm{BCS}$ & 124 & -0.17 & 0.26 & $0.76^{1}$ \\
\hline Milk & 167 & 66.38 & 392.62 & $>0.80^{2}$ \\
\hline Fat & 167 & 2.75 & 13.30 & $>0.80^{2}$ \\
\hline Protein & 167 & 2.27 & 11.84 & $>0.80^{2}$ \\
\hline Type & 143 & -0.24 & 1.33 & $>0.70^{2}$ \\
\hline Stature & 143 & -0.23 & 1.35 & $>0.70^{2}$ \\
\hline Chest width & 143 & -0.10 & 0.98 & $>0.70^{2}$ \\
\hline Body depth & 143 & -0.20 & 1.16 & $>0.70^{2}$ \\
\hline Angularity & 143 & -0.15 & 1.41 & $>0.70^{2}$ \\
\hline Rump angle & 143 & 0.10 & 1.14 & $>0.70^{2}$ \\
\hline Rump width & 143 & -0.11 & 0.91 & $>0.70^{2}$ \\
\hline Rear leg side & 143 & -0.13 & 1.10 & $>0.70^{2}$ \\
\hline Foot angle & 143 & 0.08 & 1.09 & $>0.70^{2}$ \\
\hline Udder attachment & 143 & -0.33 & 1.03 & $>0.70^{2}$ \\
\hline Udder support & 143 & -0.20 & 1.23 & $>0.70^{2}$ \\
\hline Udder depth & 143 & -0.25 & 1.14 & $>0.70^{2}$ \\
\hline Teat place rear & 143 & -0.10 & 0.98 & $>0.70^{2}$ \\
\hline Teat place side & 143 & 0.06 & 1.13 & $>0.70^{2}$ \\
\hline Teat length & 143 & -0.05 & 1.03 & $>0.70^{2}$ \\
\hline Rear udder height & 143 & -0.21 & 1.17 & $>0.70^{2}$ \\
\hline
\end{tabular}

${ }^{1}$ Personal communication, M. Coffey.

${ }^{2}$ Personal communication, R. Mrode. 


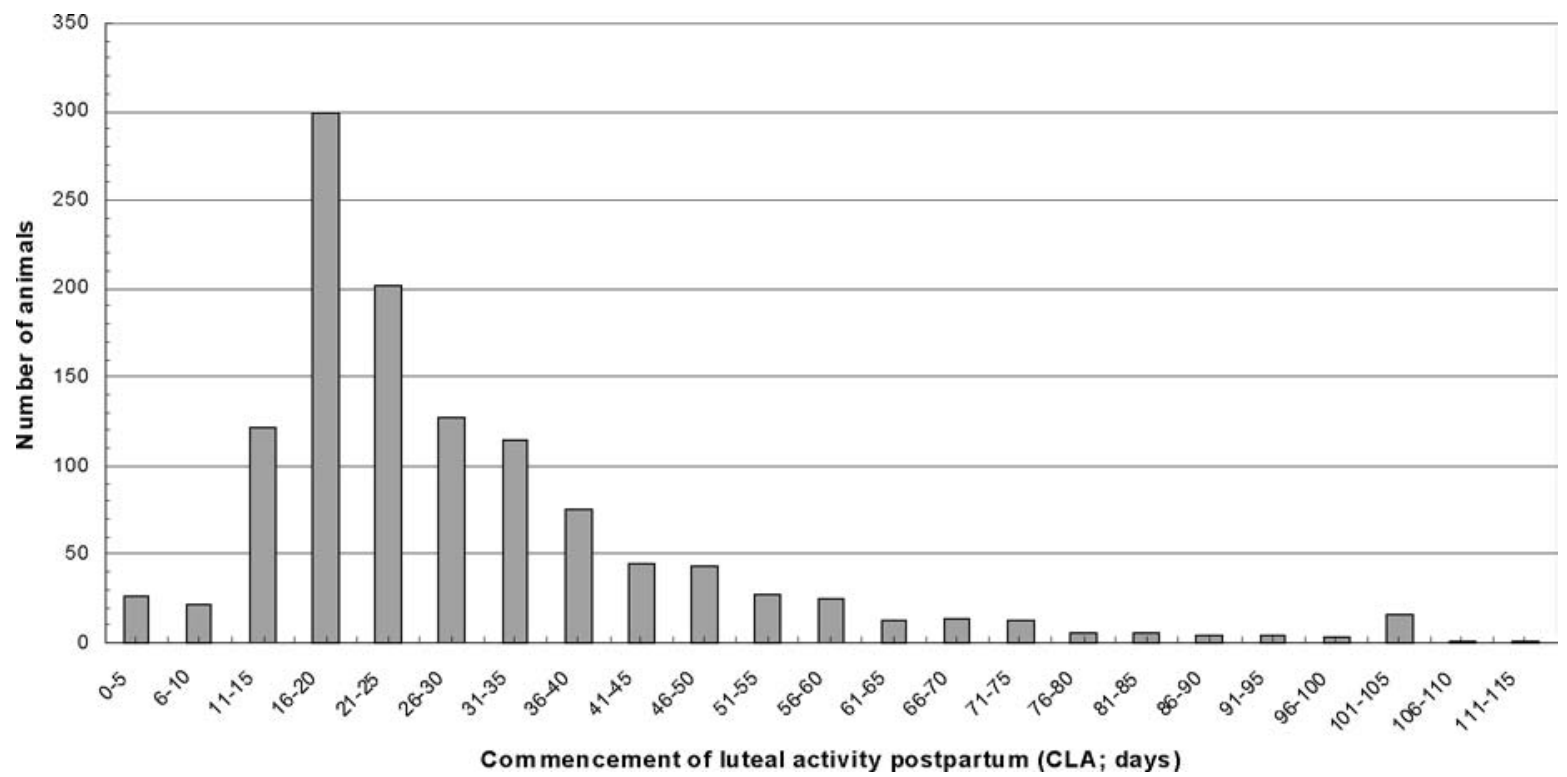

Figure 1. The frequency distribution of commencement of luteal activity (CLA) postpartum of dairy cows from 1212 lactations.

or calculated from the known pedigree using sire information and the origin of maternal ancestors. The distribution of PCH (for the cows monitored and their sires) in the database is illustrated in Royal et al. (2002b). Approximately $85 \%$ of the sires and $16 \%$ of the cows monitored in the current database were $100 \%$ North American Holstein. Approximately 7\% of the sires and 5\% of the dams were $100 \%$ British Friesian. The average percentage of North American Holsteins in the current database was $70.5 \%$.

\section{Data Integration}

The milk progesterone database formed 169 paternal half-sib groups (group sizes between one and 40 daughters). The distribution of paternal half-sib family sizes in the database is illustrated in Royal et al. (2002b). A total of 923 maternal half-sib groups were present (including singleton groups), with the largest maternal half-sib group size of three. It was not possible to identify two of the 169 sires and 31 of the dams. Those unidentified were assumed to be unique.

Restricting analyses to those with sire PTA for production reduced the number of lactations to 1207 , restricting analyses to those with sire PTA for type information reduced the number to 1094 , and restricting analyses to those with sire PTA for CI and average BCS reduced the number to 1023 .

\section{Statistical Analysis}

CLA has a long-tailed distribution (see Figure 1); therefore to improve the properties of the distribution, it is common to log-transform the data. Thus, CLA was analyzed on the natural log-transformed scale as in previous publications (Darwash et al., 1997b; Royal et al., 2002).

A mixed linear model was fitted to the data using the restricted maximum likelihood method. ASREML software (Gilmour et al., 2001) was used to estimate genetic regressions by fitting the model with an additional term for the sire PTA. Although genetic regressions provide an initial indication of genetic relationships between traits under investigation, it is possible that the PTA are not strictly independent. Only extensively used bulls were used in the current analyses; so daughters monitored using milk progesterone analysis for CLA calculation may also have been included in the calculation of PTA for the other traits in the analyses. Moreover, genetic correlations estimated using regression coefficients tend to be sensitive to the genetic variances assumed. Due to the potential bias caused by these, the results presented herein should be treated with a degree of caution. Genetic correlations were inferred from regressions by multiplying the regression coefficient $(b)$ by the ratio of the genetic standard deviations (e.g., sire PTA/lnCLA). Genetic parameters (i.e., genetic standard deviation and heritability) for lnCLA were estimated directly from the dataset, whereas published estimates were used for the traits where PTA were available (Table 3).

Principal fixed and random effects used in analyses. The fixed effects analyzed in the models were herds ( $7 \mathrm{df})$, and diet within herd ( $15 \mathrm{df})$, lactation number ( $8 \mathrm{df}$ ), year of calving ( $3 \mathrm{df}$ ), season of 
calving (3 df; Dec.-Feb., March-May, June-Aug., Sep.-Nov.). The occurrence of retained placenta (1 df), dystocia (1 df), uterine infection (1 df) and PCH (1 df) were fitted as regressions. In previous analyses of the milk progesterone database (Royal et al., 2002b), no extra variance component (i.e., permanent environmental effects) over and above the genetic variance were found when investigating repeat lactations. This was also the case in the current analyses, so the component was omitted from the final model. The possible existence of genetic components of retained placenta, uterine infection and dystocia were investigated prior to their use as fixed effects (Royal et al., 2002). These were small and not significantly different from zero, so it was assumed that any genetic influence may be ignored in the current analysis. Although only lactation number, season, and occurrence of uterine infection had significant effects upon the interval from calving to lnCLA, it was felt that the remaining effects were major in the design and thus were included in the final model. Due to the small size of the dataset, two-way and three-way interactions among herds, years, and seasons were fitted throughout as random effects in order to maintain as many genetic linkages as possible. See the Appendix for a detailed model equation.

\section{RESULTS}

The distribution of CLA in the current UK HolsteinFriesian population is illustrated in Figure 1. The raw data $(\mathrm{n}=1212)$ had a mean of $29.4 \mathrm{~d}$, a standard deviation of $18.4 \mathrm{~d}$ and a coefficient of variation of $63 \%$. This is slightly longer than the value $(\mu=27.9$, $\mathrm{SD}=15.4, \mathrm{n}=714$ ) published by Royal et al., (2000a) for a subset of this data. For further details on this parameter, see Royal et al. (2000a) and Royal et al. (2002b).

Assumed estimates for heritability $\left(\mathrm{h}^{2}\right)$ and phenotypic and genetic standard deviations $\left(\sigma_{\mathrm{P}}\right.$ and $\sigma_{\mathrm{a}}$, respectively) are presented in Table 3 . Genetic regression coefficients $(b)$ of lnCLA on sire PTA, their standard errors, and levels of significance in addition to estimated $\mathrm{r}_{\mathrm{a}}$ are presented in Table 4 .

The regression coefficient (b) of lnCLA on sire PTA for average BCS was negative and significantly different from zero $(P<0.005)$. This indicates that cows with a genetically low average BCS (thinner) are more likely to have an extended interval to lnCLA postpartum. The magnitude of this regression was such that for every increase in a BCS unit (1 to 9) at the genetic level, CLA would decrease on average by $22.4 \%$ (approximately $6 \mathrm{~d}$ ). The inferred $\mathrm{r}_{\mathrm{a}}$ was -0.84 . The distribution of average BCS breeding value of the cows (sire
PTA, assuming dam $=0$ ) is displayed in Figure 2. The best and worst animals differ by 1.64 average BCS units; therefore, the expected difference in CLA between the best and the worst cows is approximately $36.7 \%(10 \mathrm{~d})$.

The genetic regression coefficient of daughter lnCLA on sire PTA for CI approached significance $(P<0.1)$, and the inferred $\mathrm{r}_{\mathrm{a}}$ was 0.36 . This correlation indicates that cows with genetically longer CI on average tend to have a longer interval to CLA. The magnitude of the regression was such that CLA increased by $1.1 \%$ (approximately $0.3 \mathrm{~d}$ ) with every day increase in CI. Other significant regression coefficients reflecting structure were of daughter lnCLA on PTA for chest and rump width, angularity, foot and rump angle (appropriate to $r_{a}$ range of -0.25 to 0.15 ) and udder depth (appropriate to an $\mathrm{r}_{\mathrm{a}}$ of -0.16 ).

The regression of lnCLA on milk, fat, and protein yield were all positive (appropriate to $r_{a}$ range of 0.33 to 0.69 ). The only coefficient that was significantly different from zero was the regression of InCLA on sire PTA for fat yield $(P<0.005)$. The magnitude was such that for every $10 \mathrm{~kg}$ increase in fat yield, CLA increased by $6.01 \%$ ( $1.6 \mathrm{~d}$ ). The regression on sire PTA for milk yield approached significance $(P<0.1)$.

\section{DISCUSSION}

We have clearly moved forward in our understanding of the genetic properties of fertility in dairy cattle. By relating reproductive traits that are currently less practical to measure, such as CLA, with not only milk production traits but also other traits of economic importance, we now have a much broader picture of fertility. Although few, the data analyzed here highlight two important facts that may have important implications for dairy cattle breeding. First, genetic regressions indicate that CLA may be strongly correlated genetically to sire PTA for average BCS. Second, we have obtained indications of the magnitude and sign of relationships of CLA with CI and a number of linear type traits.

The genetic relationship between fertility and BCS has been investigated from several different angles over the past few years. Pryce et al. (2000) investigated the relationship between CI and average BCS, BCS in mo 1 to 10 of lactation and BCS change between mo 1 and 2, 1 and 3, and 1 and 4 of lactation. Veerkamp et al. (2000) investigated the genetic relationship of CLA to live weight and energy balance and, in a more recent analysis (Veerkamp et al., 2001), BCS to CI and interval to first service. Finally, the current analysis estimated the genetic correlation between lnCLA and average BCS. In previously published work described 
Table 3. Assumed estimates for heritability $\left(\mathrm{h}^{2}\right)$ and phenotypic and genetic standard deviations $\left(\sigma_{\mathrm{P}}\right.$ and $\sigma_{\mathrm{G}}$, respectively).

\begin{tabular}{|c|c|c|c|c|c|}
\hline Trait & $\sigma_{\mathrm{P}}$ & $\mathrm{h}^{2}$ & $\mathrm{~h}$ & $\sigma_{\mathrm{a}}$ & Reference \\
\hline Ln CLA & 0.52 & 0.16 & 0.400 & 0.208 & $\mathrm{a}$ \\
\hline 305 milk yield (kg) & 895 & 0.39 & 0.624 & 558.927 & $\mathrm{~b}$ \\
\hline 305 fat yield (kg) & 35 & 0.47 & 0.686 & 23.995 & $\mathrm{~b}$ \\
\hline 305 protein yield $(\mathrm{kg})$ & 27 & 0.34 & 0.583 & 15.744 & $\mathrm{~b}$ \\
\hline Condition score (CS;adj 1st lac) & 1.3 & 0.28 & 0.529 & 0.688 & $\mathrm{c}$ \\
\hline Calving interval & 45.3 & 0.02 & 0.148 & 6.719 & $\mathrm{c}$ \\
\hline Type & 5.69 & 0.32 & 0.566 & 3.219 & $\mathrm{~d}$ \\
\hline Stature & 1.44 & 0.48 & 0.693 & 0.998 & $\mathrm{~d}$ \\
\hline Chest width & 1.42 & 0.25 & 0.500 & 0.710 & $\mathrm{~d}$ \\
\hline Body depth & 1.36 & 0.43 & 0.656 & 0.892 & $\mathrm{~d}$ \\
\hline Angularity & 1.37 & 0.33 & 0.574 & 0.787 & $\mathrm{~d}$ \\
\hline Rump angle & 1.31 & 0.31 & 0.557 & 0.729 & $\mathrm{~d}$ \\
\hline Rump width & 1.43 & 0.30 & 0.548 & 0.783 & $\mathrm{~d}$ \\
\hline Rear leg set & 1.08 & 0.20 & 0.447 & 0.483 & $\mathrm{~d}$ \\
\hline Foot angle & 1.3 & 0.14 & 0.374 & 0.486 & $\mathrm{~d}$ \\
\hline Fore udder attachment & 1.45 & 0.21 & 0.458 & 0.664 & $\mathrm{~d}$ \\
\hline Udder support & 1.4 & 0.23 & 0.480 & 0.671 & $\mathrm{~d}$ \\
\hline Udder depth & 1.35 & 0.33 & 0.574 & 0.776 & $\mathrm{~d}$ \\
\hline Teat placement rear & 1.39 & 0.28 & 0.529 & 0.736 & $\mathrm{~d}$ \\
\hline Teat placement side & 1.32 & 0.29 & 0.539 & 0.711 & $\mathrm{~d}$ \\
\hline Teat length & 1.37 & 0.33 & 0.574 & 0.787 & $\mathrm{~d}$ \\
\hline Rear udder height & 1.41 & 0.27 & 0.520 & 0.733 & $\mathrm{~d}$ \\
\hline
\end{tabular}

\footnotetext{
${ }^{a}$ Royal et al., 2002b.

${ }^{\mathrm{b}}$ Brotherstone et al., 1997.

${ }^{\text {cPryce et al., } 2000 .}$

${ }^{\mathrm{d}}$ Brotherstone, personal communication. Apart from lnCLA where phenotypic and genetic standard deviations were calculated after adjustment for fixed effects all other phenotypic and genetic standard deviations were calculated from the raw data thus genetic standard deviation is the phenotypic variance multiplied by the heritability.
}

above (Pryce et al., 2000; Veerkamp et al., 2000, 2001), the genetic correlations estimated were negative (ranging from -0.06 to -0.88 ). Although it has often been suggested that these relationships reflect a yield effect upon fertility, attempts were made to account for yield by both Veerkamp et al. (2000) and Pryce et

Table 4. Genetic regression coefficients $(b)$ of lnCLA on sire PTA for production, BCS, calving interval, and linear type traits and the inferred genetic correlations $\left(\mathrm{r}_{\mathrm{a}}\right)$.

\begin{tabular}{lllclr}
\hline PTA & 1 & 9 & $b(\mathrm{SE})$ & F probability & $\left(\mathrm{r}_{\mathrm{a}}\right)$ \\
\hline 305 milk yield kg & $\ldots$ & $\ldots$ & $0.00013(0.000073)$ & 0.1 & 0.36 \\
305 fat yield kg & $\ldots$ & $\ldots$ & $0.006(0.0019)$ & 0.005 & 0.69 \\
305 protein yield kg & $\ldots$ & $\ldots .0043(0.0025)$ & 0.1 & 0.33 \\
Condition score & Thin & Fat & $-0.253(0.0862)$ & 0.005 & -0.84 \\
Calving interval (d) & $\ldots$ & $\ldots$. & $0.011(0.0095)$ & n.s. & 0.36 \\
Type & Low & High & $0.0099(0.024)$ & n.s. & 0.15 \\
Stature & Small & Tall & $-0.021(0.022)$ & n.s. & -0.10 \\
Chest width & Narrow & Wide & $-0.067(0.020)$ & 0.001 & -0.23 \\
Body depth & Shallow & Deep & $-0.037(0.024)$ & n.s. & -0.16 \\
Angularity & Coarse & Angular & $0.04(0.021)$ & 0.05 & 0.15 \\
Rump angle & High pins & Low pins & $-0.010(0.020)$ & 0.05 & -0.04 \\
Rump width & Narrow & Wide & $-0.066(0.023)$ & 0.005 & -0.25 \\
Rear leg set & Posty & Sickled & $0.0054(0.018)$ & n.s. & 0.01 \\
Foot angle & Low & Steep & $-0.039(0.018)$ & 0.005 & -0.09 \\
Fore udder attachment & Loose & Tight & $-0.040(0.023)$ & 0.1 & -0.13 \\
Udder support & Broken & Strong & $0.0069(0.019)$ & n.s. & 0.02 \\
Udder depth & Deep & Shallow & $-0.042(0.020)$ & 0.05 & -0.16 \\
Teat placement rear & Wide & Close & $-0.009(0.022)$ & n.s. & -0.03 \\
Teat placement side & Close & Apart & $0.015(0.019)$ & n.s. & 0.05 \\
Teat length & Short & Long & $-0.015(0.021)$ & n.s. & -0.06 \\
Rear udder height & Very low & Very high & $-0.026(0.021)$ & n.s. & -0.09 \\
\hline
\end{tabular}

${ }^{1} \mathrm{NS}=$ not significant. 


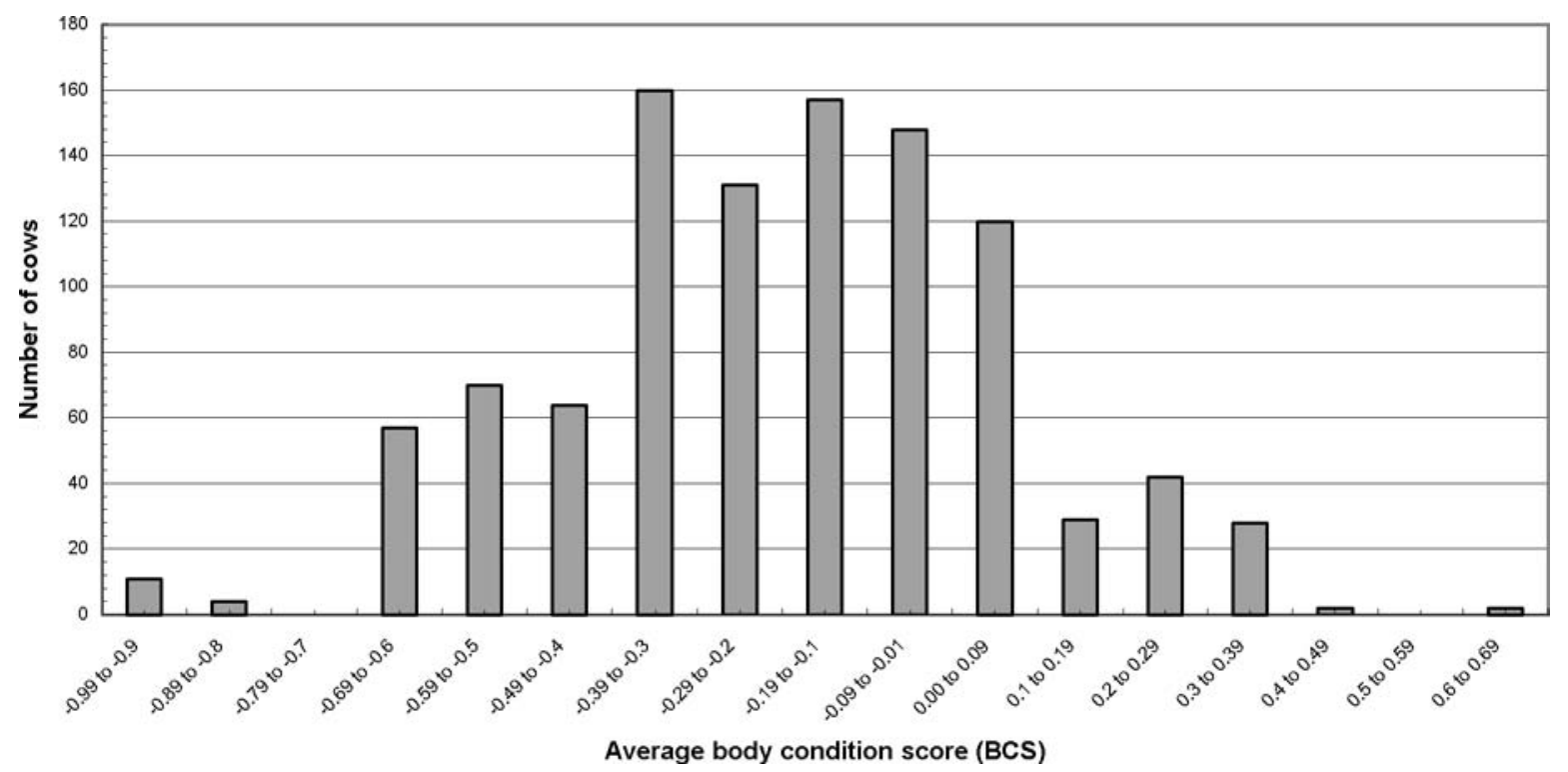

Figure 2. Frequency distribution of cow estimated breeding value (equal to PTA of sire, assuming dam $=0$ ) for average BCS $(n=1023)$.

al. (2000), albeit by phenotypic adjustment. In both cases, correlations remained negative and of substantial magnitude, supporting the hypothesis that body tissue mobilization and partitioning for the purpose of production may occur as a result of some of the same processes that affect reproduction. The genetic correlations between BCS (energy balance), milk yield, and fertility are likely to reflect pleiotrophic gene action (i.e., a gene affecting two or more characters [Falconer and Mackay, 1996]). Thus, the genetic correlation could lie through either 1) hormones such as insulin, growth hormone, and insulin-like growth factors controlling intermediary metabolism (metabolic pathways by which the basic molecular building blocks in a cell are interconverted and incorporated into larger molecules) having direct effects on ovarian function or 2) reproductive hormones regulating ovarian function having direct effects on intermediary metabolism.

The physiological basis for these relationships may be as follows. Negative energy balance, responsible for the loss of BCS as occurs during peak lactation, is associated with changes in the secretion and circulating levels of a wide range of hormones. In particular, hormones controlling intermediary metabolism lead to the onset of gluconeogenesis and the mobilization of energy stored in the form of carbohydrates, fat, and protein. Selective breeding for high milk yield affects the same hormone systems: in high-yielding cows, circulating levels of growth hormone and corticosteroids are raised, while those of insulin and IGF-I are lowered (Breier et al., 1986; Rutter et al., 1989; Richards et al., 1991). The decrease in circulating insulin may cause the decrease in IGF-I, despite the increase in growth hormone, through a reduction in hepatic growth hormone receptor expression. All of these hormone changes may cause a delay in CLA, as all have effects on follicle development.

Selection for high yield, in addition to reducing overall energy balance, liveweight, and BCS (Veerkamp and Koenen, 1999), leads to alterations in circulating levels of reproductive hormones. For instance, in severe cases of negative energy balance, gonadotrophin secretion is blocked and ruminants become anoestrus (Jolly et al., 1995). It appears that gonadotrophin secretion is affected by selection for milk yield, since Gong et al. (2000) demonstrated a decreased LH pulse frequency and a decreased response to GnRH in cows selected for high yield. Furthermore, Royal (1999) and Royal et al. (2000c) provided evidence to suggest that a substantial proportion of phenotypic variation in the LH response to a GnRH challenge in prepubertal Holstein-Friesian heifers is due to additive genetic variation $\left(h^{2}=0.51\right)$. Since $\mathrm{LH}$ pulse frequency is one of the critical factors inducing onset of ovarian cyclicity postpartum (Jolly et al., 1995), this may be significant in the aetiology of subfertility. Hence, this trait may be of potential interest to dairy cattle selection programs to improve fertility. In addition to $\mathrm{LH}$, other reproductive hormones (FSH and prolactin) may also be involved. Leptin may have a role in mediating these effects because it can act directly to induce the release of LH and FSH from bovine pituitary glands (Liou et al., 1997; Yu et al., 1997). Recent work by Kadokawa et 
al. (2000) has reported a phenotypic correlation (0.83) between the interval from parturition to the leptin nadir and the interval to first postpartum ovulation, suggesting that a delay in leptin recovery postpartum is associated with an extended CLA. There are no reports to our knowledge suggesting differences in leptin levels between high and low genetic merit dairy cattle, and a recent analysis by Royal et al. (2002a) found that additive genetic variation was not responsible for any variation observed in plasma leptin concentrations in prepubertal Holstein-Friesian heifers. However, they concluded that since high heritabilities were obtained in pigs at later stages of maturity (Cameron et al., 2000), genetic variation in dairy heifers may increase following expression of different genes or following metabolic challenge later in life.

The current work to investigate the relationships between linear type traits and CLA is relevant because linear type traits feature in most breeding programs and are good predictors of live weight and condition score (Veerkamp and Brotherstone, 1997). A number of the regression coefficients between fertility (as measured by CLA) and linear type traits reported in this study are of similar magnitude and direction to those published for CI and linear type traits by Pryce et al. (1998, 2000) and Dadati et al. (1986). The current results suggest that "frailer" cows (e.g., those possessing one or more of the following characteristics: angular, thin, narrow-chested, narrow-rumped, or high-pinned) on average will have reduced fertility, as measured by extended CLA. Cows with the opposite attributes are often referred to as "stronger," and such cows appear to have better fertility, which is in agreement with Dadati et al. (1986).

This work thus supports and furthers that of Pryce et al. (2000) and Veerkamp et al. (2000), showing that average BCS and some type traits may also be used to predict fertility, measured by CLA in this study, an important prerequisite for high fertility.

The genetic regression of lnCLA on PTA CI was moderate and favorable, appropriate to a genetic correlation of 0.36 . Although CLA is free from management decisions, CI proofs may be biased by many managerial influences. Therefore, it is possible that the regression may be either inflated or deflated. For example, interval to first service in high genetic merit cows may be extended for management reasons (over and above the $\mathrm{r}_{\mathrm{a}}$ with yield) to prolong lactation in comparison to their lower-yielding herd mates. If this were the case, sires of high genetic merit cows may be given a lower ranking for CI than their true breeding value, that is, their PTA would be biased upwards. The regression of InCLA on sire PTA for CI was affected by a small number of cows in the sire groups of PTA $\geq 6.5$ d, which had a relatively low CLA. This may reflect the inclusion in the database of some cows with exceptionally long CI for management reasons, in view of the relatively long (600-d) restriction applied to CI in estimating (co)variance compounds for this parameter. Following exclusion of the 46 animals in this range (PTA $\geq 6.5$ ), the regression of InCLA on sire PTA for CI was 0.021 ( $\mathrm{SE}=0.010 ; P<0.05)$ and appropriate to a genetic correlation of 0.69 .

Alternatively, cows that are truly highly infertile will fail to have a subsequent calving due to culling for infertility. Under these circumstances, only the best of the sire's daughters will have a CI and the bull PTA for CI may be biased downwards. This has been partially corrected for when estimating CI PTA used in this analysis by using bivariate models for the estimation of PTA values that include traits such as yield to help correct for missing data (Pryce et al., 2000). Therefore, we would predict that in this particular analysis, it is more likely that the regression of lnCLA on PTA CI is biased downwards.

Genetic regressions of InCLA on updated PTA for milk, fat, and protein yield were positive and agreed with those reported previously by Royal et al. (2002b) and with estimates by Veerkamp et al. (2000). Cows with the genetic potential to produce higher yields tend to have an extended CLA. Therefore, the drive towards milk yield has resulted, in part, in reduced fertility. However, although the genetic relationships between fertility and milk yield are unfavorable, they are not 1 , so selection for fertility using a designed index does not have to reduce milk yield or compromise selection for other traits of economic importance (Pryce et al., 2000b also demonstrates this).

Important implications of these findings are that, because CLA has a moderate heritability and is measurable in all animals rather than only those that complete a lactation and calve again, it may be possible to produce more accurate sire PTA for fertility (compared to PTA for traditional fertility traits such as CI) while using smaller progeny test groups. Therefore, CLA should be considered for inclusion in a fertility index.

This research has added to our understanding of CLA. A substantial component of the observed variation in CLA is an attribute of the individual and is genetic in origin (i.e., not simply a result of chance events experienced by the cow and errors in measurement). The observed variation is not only phenotypically correlated to traditional measures of fertility (Darwash et al., 1997a; Royal et al., 2002), but we now have the first evidence of a potential genetic correlation between CLA and CI, a traditional measure of fertility. The genetic relationship of CLA to other com- 
ponents of a proposed fertility index, such as production and type (as investigated here), appears to be substantial and significant, which has positive implications for the evaluation of CLA as a candidate trait for fertility in selection indexes. Furthermore, with the availability of on-line milk progesterone monitoring systems (likely within the next $5 \mathrm{yr}$ ) providing rapid progesterone profiles, the measurement of endocrine fertility parameters, and hence, estimation of breeding values using these measurements, will become more cost effective and more incisive. Since CLA appears to be a good predictor of average BCS, endocrine measurements of fertility may reduce the need for routine condition score assessment. In the meantime, type, production, average BCS, and other traditional measures of fertility such as CI should be used to halt or at least reduce the genetic decline in fertility.

\section{CONCLUSIONS}

Although data analyzed here were small, the findings have significantly improved our knowledge of endocrine parameters. The data presented herein illustrate that endocrine fertility traits such as CLA (coupled with the use of online milk progesterone monitoring) may have the potential to help improve the accuracy of breeding value prediction for fertility if incorporated into fertility indices based on traditional fertility traits. This would allow producers to make more informed selection decisions. However, further studies with larger datasets are needed in order to refine the genetic associations of CLA with CI and other traits of economic importance.

\section{ACKNOWLEDGMENTS}

The financial support by the Milk Development Council and the Department of Environment Food and Rural Affairs is gratefully acknowledged. We are grateful to National Milk Records plc for information on monthly milk production and to HUKI for pedigree details. We thank S. Brotherstone, M. Grossman, and Mike Coffey for their constructive comments during the preparation of this manuscript and for assistance in data preparation. Furthermore, we acknowledge the support, enthusiasm, and commitment of herd owners and their herdsmen for collection of milk samples and field data.

\section{REFERENCES}

Beam, S. W., and W. R. Butler. 1999. Energy balance effects on follicular development and first ovulation in post-partum cows. J. Repod. Fert. 54:411-424.

Breier, B. H., J. J. Bass, J. H. Butler, and P. D. Gluckman. 1986. The somatotrophic axis in young steers: Influence of nutritional status on pulsatile release of growth hormone and circulating concentrations of insulin-like growth factor. J. Endocrin. 111:209-215.

Brotherstone, S., and W. G. Hill. 1991. Dairy herd life in relation to linear type traits and production. 1. Phenotypic and genetic analyses in pedigree type classified herds. Anim. Prod. 53:279-287.

Brotherstone, S., R. F. Veerkamp, and W. G. Hill. 1997. Genetic parameters for a simple predictor of lifespan of HolsteinFriesian dairy cattle and its relationship to production. Anim. Sci. 65:31-37.

Butler, W. R., and R. D. Smith. 1989. Interrelationships between energy balance and post-partum reproductive function in dairy cattle. J. Dairy Sci. 72:767-783.

Cameron, N. D., J. C. Penman, and E. McCullough. 2000. Serum leptin concentration in pigs selected for high or low daily food intake. Gen. Res. 75:209-213.

Dadati, E., B. W. Kennedy, and E. B. Burnside. 1986. Relationships between confirmation and calving interval in Holstein cows. J. Dairy Sci. 69:3112-3119.

Darwash, A. O., J. A. Woolliams, and G. E. Lamming. 1997a. The phenotypic association between the interval to postpartum ovulation and traditional measures of fertility in dairy cattle. Anim. Sci. 65:9-16.

Darwash, A. O., J. A. Woolliams, and G. E. Lamming. 1997b. Estimation of genetic variation in the interval from calving to postpartum ovulation in dairy cows. J. Dairy Sci. 80:1227-1234.

Darwash, A. O., G. E. Lamming, and J. A. Woolliams. 1999. The potential for identifying heritable endocrine parameters associated with fertility in postpartum dairy cows. Anim. Sci. 68:333-347.

Falconer, D. S., and T. F. C. Mackay. 1996. Introduction to Quantitative Genetics. 4th ed. Longman, Harlow, UK.

Gilmour, A. R., R. Thompson, B. R. Cullis, and S. Welham. 2001. ASREML User's Manual (ftp://ftp.res.bbsrc.ac.uk/pub/aar).

Gong, J. G., W. L. Lee, and A. Moghaddam. 2000. LH secretion and response to GnRH during the early postpartum period in dairy cows undergoing genetic selection for milk yield. J. Reprod. Fert. Abstr. Series 25. 57.

Groeneveld, E. 1998. REML VCE a multivariate multi model restricted maximum likelihood (co)variance estimation package version 4 User's guide.

Jolly, P. D., S., McDougall, L. A., Fitzpatrick, K. L., Macmillan, and K. W. Entwistle. 1995. Physiological effects of undernutrition on postpartum anoestrus cows. J. Reprod. Fert. Suppl. 49: 477-492.

Juga, J., E. Mantysaari, and J. Poso. 1999. Economic response to total merit selection in Finnish Ayrshire breeding. GIFT, Nov 7-9th, The Netherlands.

Kadokawa, H., D., Blache, Y. Yamada, and G. B. Martin. 2000. Relationship between changes in plasma concentrations of leptin before and after parturition and the timing of first postpartum ovulation in high-producing Holstein dairy cows. Reprod. Fert. Develop. 12:405-411.

Liou, S. S., J. M. Lim, R. M. Blair, and W. Hansel. 1997. Leptin causes the release of $\mathrm{LH}$ and FSH from perfused murine and bovine pituitary glands. Biol. Reprod. 56(Suppl. 1):354. Abstr.

Pryce, J. E., R. J. Esslemont, R. Thompson, R. F. Veerkamp, M. A. Kossaibati, and G. Simm. 1998. Estimation of genetic parameters using health, fertility and production data from a management recording system for dairy cattle. Anim. Sci. 66:577-584.

Pryce, J. E., and R. F. Veerkamp. 1999. The incorporation of fertility indices in genetic improvement programmes. Br. Soc. Anim. Sci. Occasional Mtg. Pub. 26. Vol 1.

Pryce, J. E., M. P. Coffey, and S. Brotherstone. 2000. The genetic relationship between calving interval, body condition score and linear type and management traits in registered Holsteins. J. Dairy Sci. 83:2664-2671.

Richards, M. W., R. P. Wettemann, L. J. Spicer, and G. L. Morgan. 1991. Nutritional anestrus in beef cows-effects of body condition score and ovariectomy on serum luteinizing-hormone and insulin-like growth factor-I. Biol. Reprod. 44:961-966. 
Royal, M. D. 1999. Genetic variation in endocrine parameters of fertility. PhD thesis. University of Nottingham.

Royal, M.D., A. O. Darwash, A. P. F. Flint, R. Webb, J. A. Woolliams, and G. E. Lamming. 2000a. Declining fertility in dairy cattle: Changes in traditional and endocrine parameters of fertility. Anim. Sci. 70:487-501.

Royal, M. D., J. A. Woolliams, R. Webb, and A. P. F. Flint. 2000b. Estimation of genetic variation in the interval from parturition to commencement of luteal activity in Holstein-Freisian dairy cows. J. Reprod. Fert. Abstract Ser. 25. Abstr. 74.

Royal, M. D., A. O. Darwash, A. P. F., Flint, R. Webb, G. E. Lamming, and J. A. Woolliams. 2000c. Estimation of genetic variation in the $\mathrm{LH}$ response to a $\mathrm{GnRH}$ challenge in pre-pubertal HolsteinFriesian heifers. Proc. Brit. Soc. Anim. Sci.

Royal, M. D., A. P. F. Flint, and J. A. Woolliams. 2002. Genetic and phenotypic relationships among endocrine and traditional fertility traits and production traits in Holstein-Friesian dairy cows. J. Dairy Sci. 85:958-967.

Royal, M. D., A. P. F. Flint, R. Webb, D. Blache, and J. A. Woolliams. Estimation of genetic variation in plasma leptin concentrations in pre-pubertal heifers. Proc. Brit. Soc. Anim. Sci. (In press).

Rutter, L. M., R. Snopek, and J. G. Manns. 1989. Serum concentrations of IGF-I in postpartum beef-cows. J. Anim. Sci. 67:2060-2066.

Veerkamp, R. F., and S. Brotherstone. 1997. Genetic correlations between linear type traits, food intake, live weight and condition score in Holstein Friesian dairy cattle. Anim. Sci. 64:385-392.

Veerkamp, R. F., and E. P. C. Koenen. 1999. Genetics of food intake, liveweight, condition score and energy balance. BSAS Occasional Publication on Metabolic Stress in Dairy Cows. 24:63-73.

Veerkamp, R. F., J. K. Oldenbroek, H. J. van der Gaast, and J. H. J. van der Werf. 2000. Genetic correlation between days until start of luteal activity and milk yield, energy balance and live weights. J. Dairy Sci. 83:577-583.

Veerkamp, R. F., E. P. C. Koenen, and G. De Jong 2001. Genetic correlations among body condition score, yield and fertility in first parity cows estimated by random regression models. J. Dairy Sci. 84:2327-2335.

Yu, W. H., M. Kimura, A. Walczewska, S. Karanth, and S. M. McCann. 1997. Role of leptin in hypothalamic-pituitary function. Proc. Nat. Acad. Sci. USA. 94:1023-1028.

\section{APPENDIX}

The initial statistical model used to investigate effects on the trait $\operatorname{lnCLA}(\mathrm{Y})$ was as follows.

$$
\begin{gathered}
\mathrm{Y}_{\mathrm{ijklmnopqrs}}=\mu+\mathrm{L}_{\mathrm{i}}+\mathrm{H}_{\mathrm{j}}+\mathrm{Y}_{\mathrm{k}}+\mathrm{S}_{\mathrm{l}}+\mathrm{D}_{\mathrm{m}}+\mathrm{U}_{\mathrm{n}}+\mathrm{R}_{\mathrm{o}} \\
+\mathrm{C}_{\mathrm{p}}+\Sigma_{\mathrm{q}=1,2} \beta_{\mathrm{q}} \mathrm{X}_{\mathrm{q}}+\mathrm{HY}_{\mathrm{jk}}+\mathrm{HS}_{\mathrm{jl}}+\mathrm{YS}_{\mathrm{kl}} \\
+\mathrm{HYS}_{\mathrm{jkl}}+\mathrm{A}_{\mathrm{r}}+\mathrm{P}_{\mathrm{r}}+\mathrm{E}_{\mathrm{ijkl}} \text { nopqrs }
\end{gathered}
$$

where fixed effects are:

$$
\begin{aligned}
\mu & =\text { overall mean } \\
L_{\mathrm{j}} & =\text { lactation number }(\mathrm{i}=1 \text { to } 9) \\
\mathrm{H}_{\mathrm{j}} & =\text { herd }(j=1 \text { to } 9) \\
\mathrm{Y}_{\mathrm{k}} & =\text { year of calving }(\mathrm{k}=1995 \text { to } 1998) \\
\mathrm{S}_{\mathrm{l}} & =\text { season of cavling }(l=1 \text { to } 4) \\
\mathrm{D}_{\mathrm{m}} & =\operatorname{diet}(m=1 \text { to } 23) \\
\mathrm{U}_{\mathrm{n}} & =\text { uterine infection }(\mathrm{n}=0 \text { or } 1) \\
\mathrm{R}_{\mathrm{o}} & =\text { retained placenta }(\mathrm{o}=0 \text { or } 1) \\
\mathrm{C}_{\mathrm{p}} & =\text { dystocia }(\mathrm{p}=0 \text { or } 1) \\
\mathrm{B}_{\mathrm{q}} \mathrm{X}_{\mathrm{q}} & =\text { regression variable }(\mathrm{q}=1 \text { or } 2) \text { where: } \\
\mathrm{X}_{1} & =\text { percentage of Holstein genes, and } \\
\mathrm{X}_{2} & =\text { sire PTA for the trait to be investigated }
\end{aligned}
$$

and where random effects are:

$$
\begin{aligned}
\mathrm{HY}_{\mathrm{kj}}= & \text { herd-year interaction }\left(\mathrm{N}\left(0, \sigma_{\mathrm{HY}}{ }^{2}\right)\right. \\
\mathrm{HS}_{\mathrm{jl}}= & \text { herd-season interaction }\left(\mathrm{N}\left(0, \sigma_{\mathrm{HS}}{ }^{2}\right)\right. \\
\mathrm{YS}_{\mathrm{kl}}= & \text { year-season interaction }\left(\mathrm{N}\left(0, \sigma_{\mathrm{YS}}{ }^{2}\right)\right. \\
\mathrm{HYS}_{\mathrm{kl}}= & \text { herd-year-season interaction }\left(\mathrm{N}\left(0, \sigma_{\mathrm{HYS}}{ }^{2}\right)\right. \\
\mathrm{A}_{\mathrm{r}}= & \text { breeding value }\left(\mathrm{N}\left(0, \sigma_{\mathrm{A}}{ }^{2} \mathbf{A}\right) \text { where } \mathbf{A}\right. \text { is the } \\
& \text { numerator relationship matrix of cows } \\
& \text { available in the data } \\
\mathrm{P}_{\mathrm{r}}= & \text { individual }\left(\mathrm{N}\left(0, \sigma_{\mu}{ }^{2}\right)\right. \\
\mathrm{E}_{\mathrm{ijk} l m n o p q r s}= & \text { error }\left(\mathrm{N}\left(0, \sigma_{\mathrm{E}}{ }^{2}\right)\right.
\end{aligned}
$$

